\title{
Screening for lead exposure in children in Belize
}

\author{
Andreas Charalambous, ${ }^{1}$ Katie Demoliou, ${ }^{1}$ Marco Mendez, ${ }^{2}$ \\ Robert Coye, ${ }^{3}$ Giovanni Solorzano, ${ }^{4}$ and Elena Papanastasiou ${ }^{5}$
}

Suggested citation Charalambous A, Demoliou K, Mendez M, Coye R, Solorzano G, Papanastasiou E. Screening for lead exposure in children in Belize. Rev Panam Salud Publica. 2009;25(1):47-50.

ABSTRACT Objectives. The objectives of this pilot study were to determine the blood lead levels in children in Belize and to try to relate these findings to demographic variables.

Methods. With permission from parents, capillary blood was collected from the fingers of 164 children with an age range of 2 to 8 years, living and attending school in the spring of 2002 in four towns: Belize City, San Pedro, Orange Walk, and Benque Viejo. The sample represents $0.4 \%$ of all children in Belize in that age range. Lead levels were analyzed by the method of anodic stripping voltammetry using the ESA LeadCare analyzer.

Results. The mean blood lead level for the children in the sample was 4.94 micrograms per deciliter $(\mu \mathrm{g} / \mathrm{dL})$ with a standard deviation of 2.46. However, 11 children (7\%) had blood lead in the range of 10.1-13.8 $\mu \mathrm{g} / \mathrm{dL}$, which is the level of concern according to guidelines of the Centers for Disease Control and Prevention. Children living in the large urban centers of $\mathrm{Be}-$ lize City and Orange Walk town had higher lead levels (mean 5.80 and $5.74 \mu \mathrm{g} / \mathrm{dL}$ ) than children living in the smaller towns of Benque Viejo and San Pedro (mean 4.17 and $4.63 \mu \mathrm{g} / \mathrm{dL}$ ). There were no statistically significant differences between male and female children.

Conclusions. These data indicate that children in Belize are being exposed to lead and suggest that this pilot study be followed up with a comprehensive study with a larger sample and correlation of the findings to socioeconomic characteristics, to children's behavior, and to the home and school environment.

Key words Lead, mass screening, Belize.

The Centers for Disease Control and Prevention (CDC) in the United States of America consider low-dose exposure to lead poisoning in children to be a pre-

\footnotetext{
1 Department of Health and Life Sciences, University of Nicosia, Nicosia, Cyprus. Send correspondence and reprint requests to: Andreas Charalambous, Department of Health and Life Sciences, University of Nicosia, 46 Makedonitissas Avenue, PO Box 24005, Nicosia 1700, Cyprus; telephone: 35722 841565; fax: 35722352067.

2 Physician, Orange Walk Town, Belize.

3 Physician, Belize City, Belize.

4 Physician, San Perdo Town, Belize.

5 Department of Education, University of Nicosia, Nicosia, Cyprus.
}

ventable pediatric health problem and have emphasized the need for primary prevention (1). The CDC has defined a value for an elevated blood lead level of 10 micrograms per deciliter $(\mu \mathrm{g} / \mathrm{dL})$ as the level of concern. Sources for lead exposure by inhalation or ingestion for children include leaded gasoline, industrial emissions, lead-based paint materials, indoor dust, and soil (2). Chronic subclinical levels of lead toxicity as low as $10 \mu \mathrm{g} / \mathrm{dL}$, which may be asymptomatic in most cases, can have long-term effects on children's cognitive development and behavior, including aggression, decreased attention span, hyperactivity, and antisocial or delinquent behavior (3-5). On the basis of this evidence, the American Academy of Pediatrics has issued recommendations on screening for elevated blood lead levels and prevention measures (6), which include anticipatory guidance by physicians, educating parents, removing environmental lead sources, and universal screening of all children if the prevalence of elevated blood lead levels in the community is unknown or if more than $27 \%$ of the housing in the community was built before 1950. For longterm management, reducing exposure 
has been evaluated to be the most important modality (7). Educational intervention on the importance of reducing lead exposure, on nutrition and dust clean-up practices, and on behavioral changes has been shown to be an effective component of primary prevention programs to reduce blood lead levels (8).

Chronic low levels of lead in blood have not been addressed as a problem for children in Belize. Pediatricians do not routinely screen children for lead exposure, and so no data are available to evaluate blood lead levels and lead exposure in children of preschool and elementary school age. This study, conducted in the spring of 2002, represents the first attempt to examine whether children in Belize, and especially those living in an urban environment, are being exposed to lead and to correlate these findings with demographic variables.

\section{MATERIALS AND METHODS}

Four locations in Belize were chosen to carry out this study: the island town of San Pedro, the coastal town of Belize City, and two inland towns-Orange Walk and Benque Viejo. Belize City and Orange Walk represent the largest urban centers of Belize, with populations of 49050 and 13 483, respectively. During the 2000 census, the population of San Pedro was 4499 persons and that of Benque Viejo was 5066 persons (9). A total of 200 families with children of primary school age were contacted through the principals of six primary schools after permission was sought and given by the Belize Ministry of Education and the Ministry of Health. Two schools were located in Belize City, two in Orange Walk, one in Benque Viejo, and one in San Pedro. An open testing day also took place for all children in San Pedro. Five of the six schools are Roman Catholic and one is privately owned. The Roman Catholic schools were chosen because they represented the largest schools in each town in terms of student enrollment. Informed consent to obtain capillary blood from the child's finger was obtained from 174 guardians who volunteered to participate in the study and answer a questionnaire. Refusal to participate was primarily due to parents' concern that hygiene precautions may not be followed and their concern about putting their children under stress. Other reasons given were religion, the child's health, or parents forgetting to return the consent forms. The final number of blood samples collected was reduced to 164 because of either the absence of the child on the day of collection (three children) or the child's refusal to participate (seven children).

The questionnaires administered to the guardians addressed socioeconomic factors, medical history, development and achievements at school, unusual behavior, and behavioral characteristics such as hand-to-mouth activity and type and hours of play. To assess environmental exposure at home and at school, information was requested about the house in which the child lived and about a house where the child may spend time outside school hours (with grandparents, other relatives, or a child-minder) as well as about the school the child attended, the use of glazed pottery cookware, and the presence of old car batteries around the house. With regard to buildings, information was obtained about the age of the building, type of plumbing, paint, floors, playgrounds, distance from the road, traffic load, and proximity to industrial sites. When required, teachers, medical student volunteers, or the principal of the school helped parents complete the questionnaires.

Capillary blood sampling took place at school sites. Before a blood sample was obtained, the hand of each child was washed thoroughly in warm water with a neutral glycerin-based soap, and each finger and nail was scrubbed individually with a plastic brush. The hand was then rinsed in clean water and dried with white tissue. The child's finger was then cleaned with an alcohol swab, dried with sterile gauze, and pierced with a disposable blood lancet (Vitrex, $1.0 \mathrm{~mm}$; Vitrex Medical Ltd. UK). Fifty microliters of blood was removed using a calibrated lead-free capillary tube (ESA, Inc. USA). Excess blood was wiped off with gauze and then the tube was transferred into the ESA treatment reagent tube and mixed thoroughly. The child's finger was wiped off with an alcohol swab and bandaged. Samples were stored at $4^{\circ} \mathrm{C}$ and analyzed within 24 hours after mixing with a vortex mixer. A $50-\mu \mathrm{L}$ reagent mix was removed for the measurement of lead with the LeadCare System (blood lead level range 1.4-65 $\mu \mathrm{g} / \mathrm{dL}$ ) (ESA, Inc. USA) (10) calibrated for each individual reagent kit. Measurements $>10 \mu \mathrm{g} / \mathrm{dL}$ were repeated twice after remixing. Low $(7.4 \pm 3 \mu \mathrm{g} / \mathrm{dL})$ and high $(26.7 \pm 4 \mu \mathrm{g} /$ dL) positive control samples (ESA, Inc.
USA) were used for every set of measurements. For children with blood lead levels $>10 \mu \mathrm{g} / \mathrm{dL}$, the possible source of exposure was examined from information obtained from the questionnaire, and the parents were informed by the physicians participating in the study. Guidelines were provided for reducing and eliminating sources of exposure and for reducing blood lead levels.

The results of the study were analyzed with the use of SPSS 16. Descriptive statistics such as means and percentages were used to describe the blood lead levels of the children in the sample. In addition, inferential statistics such as an analysis of variance (ANOVA) and regression were performed to determine the relationship between blood lead levels and demographic and background variables. The post hoc tests that were performed as a follow-up to the ANOVA results were done using the Bonferronitype adjustment.

\section{RESULTS}

A total of 164 children were tested. The range in age was $2-8$ years, the mean age of the children was 5.4 years, and the median and mode for age was 5 . Our sample of 164 children represents $0.4 \%$ of the total children of Belize (45052) who ranged in age from 2 to 8 years (9).

Measurements of blood lead levels showed that no children had serious lead poisoning. The mean blood lead level for the children in the sample was $4.94 \mu \mathrm{g} / \mathrm{dL}$, with a standard deviation of 2.46 . However, 11 children $(7 \%)$ had blood lead in the range of 10.1-13.8 $\mu \mathrm{g} /$ $\mathrm{dL}$, which is the level of concern according to CDC guidelines. Of the 11 children with blood lead levels $>10 \mu \mathrm{g} / \mathrm{dL}$, $6(55 \%)$ were from Orange Walk town, 2 from San Pedro, 2 from Benque Viejo, and 1 from Belize City.

The skewness and the kurtosis of the lead distribution were then tested to determine whether it would be possible to perform inferential statistics on the data. The skewness of the lead distribution in the sample was 1.37, while the kurtosis was 1.93. These slight deviations from normality did not pose any problems in further examining the data through an ANOVA, which is robust to such violations of assumptions.

The ANOVA that was performed aimed to determine whether the lead levels in the children's blood had differ- 
TABLE 1. Mean blood lead level by town, Belize, 2002

\begin{tabular}{|c|c|c|c|}
\hline Town & $\begin{array}{l}\text { Mean blood lead } \\
\text { level, } \mu \mathrm{g} / \mathrm{dL}\end{array}$ & $S D^{a}$ & $N$ \\
\hline San Pedro & 4.63 & 2.59 & 40 \\
\hline Benque Viejo & 4.17 & 1.84 & 56 \\
\hline Belize City & 5.81 & 2.13 & 18 \\
\hline Orange Walk & 5.74 & 2.80 & 50 \\
\hline Total & 4.94 & 2.46 & 164 \\
\hline
\end{tabular}

a $\mathrm{SD}=$ standard deviation

ences based on the city where they lived. The results of the analysis were statistically significant $(F=4.58, p=0.003)$, indicating that there were differences in the blood lead levels obtained in children from different cities. A post hoc analysis with the Bonferroni adjustment revealed that the only statistically significant differences were between the cities of Benque Viejo and Orange Walk ( $p=$ 0.005); Benque Viejo was the city with the least amount of lead in the children's sample. The mean lead levels were 5.80 $\mu \mathrm{g} / \mathrm{dL}$ for Belize City, $5.74 \mu \mathrm{g} / \mathrm{dL}$ for Orange Walk, $4.94 \mu \mathrm{g} / \mathrm{dL}$ for San Pedro, and $4.1 \mu \mathrm{g} / \mathrm{dL}$ for Benque Viejo. The breakdown of lead levels in children according to town and a comparison of towns are shown in Tables 1 and 2.

The mean blood lead level of male (total 93) children was $4.86 \mu \mathrm{g} / \mathrm{dL}$ and that of female (total 71) children was $5.03 \mu \mathrm{g} / \mathrm{dL}$. Therefore, a second ANOVA was performed to determine whether male and female students had different amounts of lead in their blood. The result of the analysis was not statistically significant $(F=0.203, p=0.653)$, indicating that there were no lead level differences based on gender (Table 3).

A regression analysis was also performed to determine whether the age of the children could predict the amount of lead in their blood. However, the analysis was not statistically significant $(F=$ 1.16, $p=0.283$ ), indicating that age did not influence lead levels.

\section{DISCUSSION}

Very few studies are available on environmental lead contamination in Belize, and this pilot study is the first to investigate blood lead levels in children in Belize. Although lead in gasoline was phased out by 1996, lead contamination in the soil is present. Before 1996, Belize was in the category of countries with the

TABLE 2. Mean blood level, comparison of towns, Belize, 2002

\begin{tabular}{clccc}
\hline \multirow{2}{*}{ Town I } & Town J & $\begin{array}{c}\text { Mean difference, } \\
\text { I-J }\end{array}$ & SEa $^{\mathrm{I}}$ & Significance \\
\hline \multirow{2}{*}{ San Pedro } & Benque Viejo & 0.46 & 0.49 & 1.00 \\
& Belize City & -1.18 & 0.68 & 0.50 \\
\multirow{3}{*}{ Benque Viejo } & Orange Walk & -1.11 & 0.51 & 0.18 \\
& San Pedro & -0.46 & 0.49 & 1.00 \\
& Belize City & -1.64 & 0.65 & 0.07 \\
Belize City & Orange Walk & -1.570 & 0.46 & 0.01 \\
& San Pedro & 1.18 & 0.68 & 0.50 \\
& Benque Viejo & 1.64 & 0.65 & 0.07 \\
& Orange Walk & 0.07 & 0.65 & 1.00 \\
\hline a SE = standard error. & & & &
\end{tabular}

highest allowed concentration of lead in gasoline $(0.84 \mathrm{~g} / \mathrm{L})$ (11). A study examining lead contamination of soils in Belize City indicated that lead concentrations in soil from roadside samples, schoolyards, and housing samples were at high or hazardous levels. The housing samples had the highest concentrations of lead in the soil, with a mean of 638 parts per million (12). Lead was also detected in the caudal scutes of crocodiles from two sites in northern Belize, which indicates the presence of lead in soil and water (13).

The blood lead levels of children in our sample indicate that children are being exposed to lead but below the level of concern of $10 \mu \mathrm{g} / \mathrm{dL}$ as defined by the CDC (1). The mean blood lead level in children in Belize $(4.94 \mu \mathrm{g} / \mathrm{dL})$ is below that reported for children in Bombay, India, after the phase-out of leaded gasoline (mean $8.36 \mu \mathrm{g} / \mathrm{dL}$ ) (14) but above the levels reported for Trinidad and Tobago (mean $2.8 \mu \mathrm{g} / \mathrm{dL}$ ) (15) and for the city of Nicosia, Cyprus (mean $3.0 \mu \mathrm{g} / \mathrm{dL}$ ) (16). The fact that the mean blood lead level in Belize is lower than that identified as the level of concern does not mean that Belizean children are not at risk from lead exposure. It has been shown that low-level childhood lead exposure may exert lasting effects on the developmental patterns of theta brain wave activity that are associated with developmental retardation (17) and on children's emotional and behavioral development (18).

We observed that the risk for lead exposure in children in Belize may also be associated with certain parental professions, especially mechanics, and when the workshops are located adjacent to the home. The increased risk may come from the proximity to lead batteries and, possibly, from exposure to lead-contaminated dust. In one case where the blood
TABLE 3. Mean blood lead level by gender, Belize, 2002

\begin{tabular}{lccc}
\hline & $\begin{array}{c}\text { Mean blood } \\
\text { lead level, } \\
\mu \mathrm{g} / \mathrm{dL}\end{array}$ & $\mathrm{SE}^{\mathrm{a}}$ & $\begin{array}{c}95 \% \\
\text { confidence } \\
\text { interval }\end{array}$ \\
\hline Male & 4.86 & 0.27 & $4.32-5.39$ \\
Female & 5.03 & 0.28 & $4.48-5.58$ \\
\hline
\end{tabular}

a $\mathrm{SE}=$ standard error.

lead levels were higher than $10 \mu \mathrm{g} / \mathrm{dL}$, information obtained in the questionnaire identified as the possible source of exposure the use of the dining table for repairing lead-acid car batteries. The use of lead in home-based operations is of concern in many developing countries, where lead is used in applying glaze to ceramics, producing jewelry from silver containing lead, and from recycling leadacid batteries (19). The latter seems to be of particular importance to Belize, since such home-based industries are numerous in urban centers. The extensive use of electric cars in the islands of Belize (San Pedro) is generating a large number of spent batteries and prompted the development of this home-based industry. It has been reported that this occupational hazard contributes not only to the poisoning of workers and their families but also to that of entire neighborhoods. These home-based industries should be regulated by authorities and relocated in industrial areas.

It is important that this pilot study be followed up with a large-scale study of blood lead levels of children in Belize, with a larger sample and correlation of the findings to socioeconomic characteristics, to children's behavior, and to the home and school environment. It is also necessary to statistically examine whether children living in homes older than 20 years or in close proximity to 
high-traffic roads are at higher risk for lead exposure. The same should be examined for children living in homes with painted floors, eating out of glazed ceramics, and coming into contact with car batteries. The school environment and playgrounds should be further examined in light of the findings that lead concentrations in schoolyards in Belize are at hazardous levels (12). The above recommendations represent the limitations of this pilot study.

\section{REFERENCES}

1. Centers for Disease Control and Prevention. Preventing lead poisoning in young children. Atlanta, GA: CDC, 1991.

2. Smith L. CDC recommendations on prevention and management of high blood lead levels in children. Am Fam Physician. 2008;77(8): 1175-8.

3. Brown MJ. Childhood lead poisoning prevention: getting the job done by 2010. J Environ Health. 2008;70(6):56-7.

4. Surkan PJ, Zhang A, Trachtenberg F, Daniel DB, McKinlay S, Bellinger DC. Neuropsychological function in children with blood lead levels $<10 \mathrm{microg} / \mathrm{dL}$. Neurotoxicology. 2007; 28(6):1170-7.

5. Bellinger DC. Very low lead exposures and children's neurodevelopment. Curr Opin Pediatr. 2008;20(2):172-7.

6. American Academy of Pediatrics Committee on Environmental Health. Screening for elevated blood lead levels. Pediatrics. 1998;101: 1072-8.

7. Chisolm JJ Jr. The road to primary prevention of lead toxicity in children. Pediatrics. 2001; 107:581-7.

8. Schultz B, Pawer D, Murphy A. A retrospective examination of in-home educational visits to reduce childhood lead levels. Environ Res. 1999;80:364-8.
9. Government of Belize, Central Statistical Office. Population census 2000: major findings. Belmopan, Belize: Central Statistical Office; 2000.

10. Shannon M, Rifai N. The accuracy of a portable instrument for analysis of blood lead in children. Ambulatory Child Health. 1997;3: $249-57$.

11. Onursal B, Gantam S. Vehicular air pollution experiences from seven Latin American urban centers. World Bank technical paper 373 . Washington, DC: World Bank; 1997.

12. Reeder P, Shapiro L. Lead contamination of soils in Belize City, Belize, Central America. J Environ Sci Health A Tox Hazard Subst Environ Eng. 2003;38(12):2785-805.

13. Rainwater TR, Wu TH, Finger AG, Canas JE, $\mathrm{Yu}$ L, Reynolds KD, et al. Metals and organochlorine pesticides in caudal scutes of crocodiles from Belize and Costa Rica. Sci Total Environ. 2007;373(1)146-56.

14. Nichani V, Li WI, Smith MA, Noonan G, Kulkarni M, Kodavor M, et al. Blood lead levels in children after the phase-out of leaded gasoline in Bombay, India. Sci Total Environ. 2006;363(1-3):95-106.

15. Rajkumar WS, Manohar J, Doon R, SiungChang A, Chang-Yen I, Monteil M. Blood lead levels in primary school children in Trinidad
Acknowledgement. This study was made possible through a grant from the St. Matthew's University Research Foundation. and Tobago. Sci Total Environ. 2006;361(1-3): 81-7.

16. Demoliou C, Charalambous A. Blood lead levels in children of pre-primary school age in Nicosia, Cyprus: relation to general hygiene and dust exposure. Arch Environ Health. 2004; 59(9):455-61.

17. Poblano A, Rothenberg SJ, Schnaas L, Elías Y, Cruz ML. Spatial distribution of EEG theta activity as a function of lifetime lead exposure in 9-year-old children. Neurotoxicology. 2001;22: 439-46.

18. Burns JM, Baghurst PA, Sawyer MG, McMichael AJ, Tong SL. Lifetime low-level exposure to environmental lead and children's emotional and behavioral development at ages 11-13 years. The Port Pirie Cohort Study. Am J Epidemiol. 1999;149:740-9.

19. Alliance to End Childhood Lead Poisoning and the Environmental Defense Fund. The global dimensions of lead poisoning conference report. Washington, D.C.: AECLP; May 1994.

Manuscript received on 29 May 2007. Revised version accepted for publication on 25 July 2008 .

RESUMEN Objetivos. Estudio piloto para determinar los niveles de plomo en la sangre en niños de Belice y relacionar estos valores con algunas variables demográficas.

\section{Tamizaje de la exposición al plomo en niños de Belice}

Métodos. Con el consentimiento de los padres, se tomaron muestras de sangre capilar del dedo a 164 niños de 2 a 8 años que en la primavera de 2002 vivían y asistían a la escuela en cuatro localidades: Belice, San Pedro, Orange Walk y Benque Viejo. La muestra representa $0,4 \%$ de los niños de ese grupo de edad en el país. Los niveles de plomo se analizaron mediante voltametría de redisolución anódica con un analizador ESA LeadCare.

Resultados. El nivel promedio de plomo en la sangre de los niños estudiados fue de $4,94 \mu \mathrm{g} / \mathrm{dL}$ (desviación estándar: 2,46). No obstante, 11 niños (7\%) tenían entre 10,1 y $13,8 \mu \mathrm{g} / \mathrm{dL}$ de plomo en la sangre, nivel de preocupación según los Centros de Control y Prevención de Enfermedades (CDC) de los Estados Unidos de América. Los niños que vivían en los centros urbanos grandes Belice y Orange Walk presentaron mayores niveles de plomo (valores medios: 5,80 $\mu \mathrm{g} / \mathrm{dL}$ y $5,74 \mu \mathrm{g} / \mathrm{dL}$, respectivamente) que los niños de las poblaciones más pequeñas Benque Viejo y San Pedro $(4,17 \mu \mathrm{g} / \mathrm{dL}$ y $4,63 \mu \mathrm{g} / \mathrm{dL}$, respectivamente). No se encontraron diferencias significativas entre los niños y las niñas.

Conclusiones. Estos resultados indican que los niños de Belice están expuestos al plomo y que a este estudio piloto debe seguir una investigación integral basada en una muestra mayor que correlacione los hallazgos con las características socioeconómicas, el comportamiento de los niños y el medio ambiente del hogar y la escuela.

Palabras clave Plomo, tamizaje masivo, Belice. 